\title{
Acid-assisted leaching of iron and manganese from Sri Lankan laterite: a potential source of alumina production
}

\author{
IA Goonetilleke ${ }^{1}$, HCS Subasinghe ${ }^{1}$, AS Ratnayake ${ }^{1 *}$ and DT Jayawardana ${ }^{2}$ \\ ${ }^{1}$ Department of Applied Earth Sciences, Faculty of Applied Sciences, Uva Wellassa University, Badulla. \\ ${ }^{2}$ Faculty of Applied Sciences, University of Sri Jayewardenepura, Gangodawila, Nugegoda.
}

Submitted: 02 September 2020; Revised: 13 December 2020; Accepted:26 March 2021

\begin{abstract}
Laterites are of great interest for industrial applications. This study is focussed on determining optimum conditions (i.e. $\mathrm{pH}$, temperature, and sonication time) for leaching Fe and Mn from Sri Lankan laterite. Physicochemical parameters, atomic absorption spectroscopy (AAS), X-ray diffraction (XRD), and Fourier-transform infrared (FTIR) spectroscopic analyses were performed. Different solutions were prepared for a $\mathrm{pH}$ range from 1 to 10 , temperature from $40{ }^{\circ} \mathrm{C}$ to $100{ }^{\circ} \mathrm{C}$, and sonication time from $10 \mathrm{~min}$ to $60 \mathrm{~min}$. Elemental concentrations of the filtrates were used to determine the optimum conditions. Fe and $\mathrm{Mn}$ leaching efficiencies decreased with increasing $\mathrm{pH}$ from 1 to 5 . The solution of $\mathrm{pH} 1$ indicated the maximum leaching capacities of $\mathrm{Fe}$ (17.69 ppm) and Mn (2.05 ppm). Fe and Mn leaching efficiencies almost exhibited a positive correlation with temperature. The maximum leaching concentrations were observed after $15 \mathrm{~min}$ of sonication. Therefore, the optimum conditions for leaching both $\mathrm{Fe}$ and $\mathrm{Mn}$ were determined as $\mathrm{pH} 1$ at $60^{\circ} \mathrm{C}$ temperature after 15 minutes of sonication. Precipitates of treated samples were characterised using XRD and FTIR to determine changes compared to the raw sample. XRD results identified the crystalline phases, and thereby chemical composition of raw laterite can be discovered by the software as goethite and hematite as main Fe-rich minerals. The raw laterite was also associated with gibbsite, kaolinite, and quartz. However, weak reflections of hematite were observed in the XRD spectra of treated samples. FTIR observations suggested alteration of functional groups (e.g. the disappearance of $\mathrm{Fe}-\mathrm{O}$ bond) in acid leached and sonicated samples. Consequently, FTIR and XRD results also confirmed the acid-leaching capacity of Sri Lankan laterite.
\end{abstract}

Keywords: Acid leaching, laterite, metal removal, value addition.

\section{INTRODUCTION}

Laterite is a common surficial/near surficial product of long-lasting and intensive tropical rock weathering and oxidation present in tropical countries such as Sri Lanka (Dahanayake, 1982; Pham et al., 2020). According to Persons (2012), 'laterite is a stone of a thousand uses'. The most fundamental application of laterites is as a building material. Many economically important metallic elements (e.g. $\mathrm{Al}, \mathrm{Fe}, \mathrm{Mn}, \mathrm{Ni}$ ) are present in laterites (Maiti et al., 2012; Çetintaş \& Bingöl, 2020). Therefore, the extraction of these valuable components has been the focus of many researchers. For example, minor elements such as $\mathrm{Zn}, \mathrm{Cu}, \mathrm{Ni}, \mathrm{Cd}$, and $\mathrm{Pb}$ are present in Sri Lankan laterite (Nayanthika et al., 2018). Furthermore, Sri Lankan laterites have been used in the synthesis of pure hematite nanoparticles as superior adsorption dyes (Dissanayake et al., 2019).

Metals and metal oxides present in laterites can be leached using acids, and thus enhance the $\mathrm{Al}$ content (Nasab et al., 2020). Bauxite and sillimanite are the globally prominent raw materials for the extraction of alumina and Al metal (Perks \& Mudd, 2019). Alumina has many primary and advanced applications (The

\footnotetext{
*Corresponding author(as_ratnayake@uwu.ac.lk; iD https://orcid.org/0000-0001-7871-2401)
} 
Aluminium Association, 2020). However, the availability of bauxite and sillimanite resources are limited. The industries utilising alumina as raw materials (e.g. cement industry) are urged to go for alternatives such as laterites and lateritic soils that are composed of $\mathrm{Al}_{2} \mathrm{O}_{3}$ (Moutei et al., 2018). Consequently, laterites have been leached to obtain metals such as nickel and cobalt, and to enhance the workability of laterite as a source of alumina (Goswami \& Mahanta, 2007; Liu et al., 2010; Ayanda et al., 2011; Ilyas et al., 2020). Leaching and charging behaviour of laterites are strongly dependent on the $\mathrm{pH}$ (Pham et al., 2020). However, complex mineralogy and limited application of existing technologies have caused difficulties in the processing of laterites for value addition (Nasab et al., 2020).

Sri Lankan laterite is typically yellow, deep mottled red or reddish-brown ferruginous earth with many vesicular and botryoidal structures (Dahanayake, 1982). The mineralogical composition of Sri Lankan laterite is mainly composed of goethite, hematite, gibbsite, quartz, and clay minerals (Herath \& Pathirana, 1983). However, the value addition potential of Sri Lankan laterites has rarely been focussed in the literature. Therefore, the current study is mainly focussed on investigating the metal leaching characteristics of Sri Lankan laterite. In this study, the authors investigated the optimum conditions such as $\mathrm{pH}$, temperature, and sonication time for leaching iron and manganese from Sri Lankan laterite.

\section{METHODOLOGY}

\section{Sample collection and powder sample preparation}

The representative laterite samples were collected from a quarry site in Horana-Millaniya (global position system coordinates: $6^{\circ} 38^{\prime} 59^{\prime \prime} \mathrm{N} 80^{\circ} 00^{\prime} 48^{\prime \prime} \mathrm{E}$ ) in the Southwestern Highland Complex of Sri Lanka. Samples were collected from about $1.50 \mathrm{~m}$ depth from the surface. Laterite samples were milled using a vertical planetary ball mill (Tencan XQM-0.4A, Japan) and sieved using a British standard sieve shaker to obtain the particles below $63 \mu \mathrm{m}$.

\section{Physicochemical analysis of raw laterite}

The wet and dry weight of raw laterite was measured at room temperature, and after heating at $105{ }^{\circ} \mathrm{C}$ for $24 \mathrm{~h}$, respectively. Moisture content was calculated by the difference between wet and dry weights to the initial wet weight.

About $5 \mathrm{~g}$ of the sample was ignited at $550{ }^{\circ} \mathrm{C}$ for $24 \mathrm{~h}$ using a Protherm-PLF 140/5 muffle furnace to remove organic matter. The sample was then reheated at $1050{ }^{\circ} \mathrm{C}$ for $2 \mathrm{~h}$ in the muffle furnace to evolve carbon dioxide from carbonate. Loss on ignition $\left(\mathrm{LOI}_{1050}{ }^{\circ} \mathrm{C}\right)$ was calculated by the difference between dry weight and ignited weight at $1050{ }^{\circ} \mathrm{C}$ to the dry weight (Heiri et al., 2001).

Powdered raw laterite $(<63 \mu \mathrm{m})$ was oven-dried at $80^{\circ} \mathrm{C}$ for $120 \mathrm{~min}$. About $5 \mathrm{~g}$ of raw laterite was suspended in distilled water with 1:10 soil suspension ratio, and $\mathrm{pH}$ value was measured using an $\mathrm{Edge}^{\circledR}$ Multiparameter $\mathrm{pH}$ Meter - HI2020.

\section{Determination of optimum conditions (pH range, temperature and sonication time)}

(a) Raw laterite (5 g, particles $<63 \mu \mathrm{m}$ and oven-dried at $80{ }^{\circ} \mathrm{C}$ for $120 \mathrm{~min}$ ) was suspended in $50 \mathrm{~mL}$ of distilled water. Suspension solutions were prepared from $\mathrm{pH} 1$ to 10 at room temperature. The $\mathrm{pH}$ of the solution was adjusted by adding aqueous $\mathrm{HCl}$ or aqueous $\mathrm{NaOH}$ dropwise. The mixture was filtered after $30 \mathrm{~min}$. The filtrates and precipitates were collected. The precipitates were washed with distilled water to remove unconsumed acid/base and oven-dried at $80^{\circ} \mathrm{C}$ for $60 \mathrm{~min}$.

(b) Powdered and dried laterite (5 g) samples were suspended in $50 \mathrm{~mL}$ of distilled water to determine the optimum temperature. The $\mathrm{pH}$ values of the solutions were adjusted by adding $1 \mathrm{M} \mathrm{HCl}$ drop wise. After the determination of optimum $\mathrm{pH}$ range, $\mathrm{pH} 1$ solutions were considered for further evaluation. The solutions were heated for $60 \mathrm{~min}$ at different temperatures of 40, 60, 80, and $100^{\circ} \mathrm{C}$ in a water bath. The filtrate and the precipitate were collected after filtration.

(c) Powdered and dried laterite (5 g) samples were suspended in $50 \mathrm{~mL}$ of distilled water at room temperature $\left(27^{\circ} \mathrm{C}\right)$ to determine the optimum sonication time. The $\mathrm{pH}$ values were adjusted by drop wise addition of $1 \mathrm{M}$ $\mathrm{HCl}$. The $\mathrm{pH} 1$ solution series was used to determine sonication time. The mixtures were sonicated for 10 , 15, 30, 45 and 60 min using Rocker ultrasonic cleaner sonicator (Soner 206) at room temperature at a frequency of $53 \mathrm{kHz}$. The mixtures were filtered, and the filtrate and precipitate were collected. 


\section{Sample characterisation of raw and treated laterite samples}

\section{Atomic absorption spectroscopic (AAS) analysis}

Raw laterite ( $5 \mathrm{~g}$, particles $<63 \mu \mathrm{m}$ and oven-dried at $80{ }^{\circ} \mathrm{C}$ for $2 \mathrm{~h}$ ) was dissolved in $50 \mathrm{~mL}$ of distilled water and stirred for $30 \mathrm{~min}$. Then, the mixture was filtered and the filtrate was collected to determine the water solubility of iron $(\mathrm{Fe})$, cadmium $(\mathrm{Cd})$, and manganese $(\mathrm{Mn})$ in raw laterite.

Similarly, the filtrates of treated laterite were also collected to determine the leaching concentrations of Fe, $\mathrm{Cd}$, and $\mathrm{Mn}$. Concentrations of $\mathrm{Fe}, \mathrm{Cd}$, and $\mathrm{Mn}$ in the raw and treated samples were measured using Varian AA240 atomic absorption spectrometer, after calibrating the instrument linearly using relevant standards of known concentrations.

\section{Fourier-transform infrared (FTIR) analysis}

$\mathrm{KBr}$ pellet method was used to analyse the samples. The powdered samples were mixed with potassium bromide $(\mathrm{KBr})$ at $1: 10$. The FTIR grade dried $\mathrm{KBr}$ (assay $\geq 99 \%$ ) was used. A pellet $(1 \mathrm{~mm}$ in thickness and $7 \mathrm{~mm}$ in diameter) was prepared for $\mathrm{KBr} /$ powdered sample mixture using a hand press pelletiser. The pellets of raw and treated (precipitate) laterite were placed directly in the beam of Bruker Alpha spectrophotometer over the range of $500-4000 \mathrm{~cm}^{-1}$.

\section{X-ray diffraction (XRD) analysis}

The untreated and treated precipitates of laterite samples were finely powdered. These samples were analysed via powder X-Ray Diffraction (XRD) method using Rigaku Ultima IV X-ray diffractometer with $\mathrm{Cu} \mathrm{K} \alpha$ radiation $(\lambda=1.54)$ at $40 \mathrm{kV}$ and $30 \mathrm{~mA}$. The diffractogram was recorded with a scanning rate of $0.02 \%$ in a $2 \theta$ range from $10^{\circ}$ to $60^{\circ}$.

\section{RESULTS AND DISCUSSION}

\section{Physicochemical parameters of raw laterite}

The average $\mathrm{pH}$ of powdered laterite suspension in water was 5.69. Therefore, $1 \mathrm{M} \mathrm{HCl}$ and $1 \mathrm{M} \mathrm{NaOH}$ were used to prepare solutions of $\mathrm{pH}$ below 5.69 and $\mathrm{pH}$ above 5.69, respectively. The moisture content and $\mathrm{LOI}_{1050}{ }^{\circ} \mathrm{C}$ values of raw laterite samples were $15.80 \%$ and $16.56 \%$, respectively. $\mathrm{LOI}_{1050}{ }^{\circ} \mathrm{C}$ value indicates

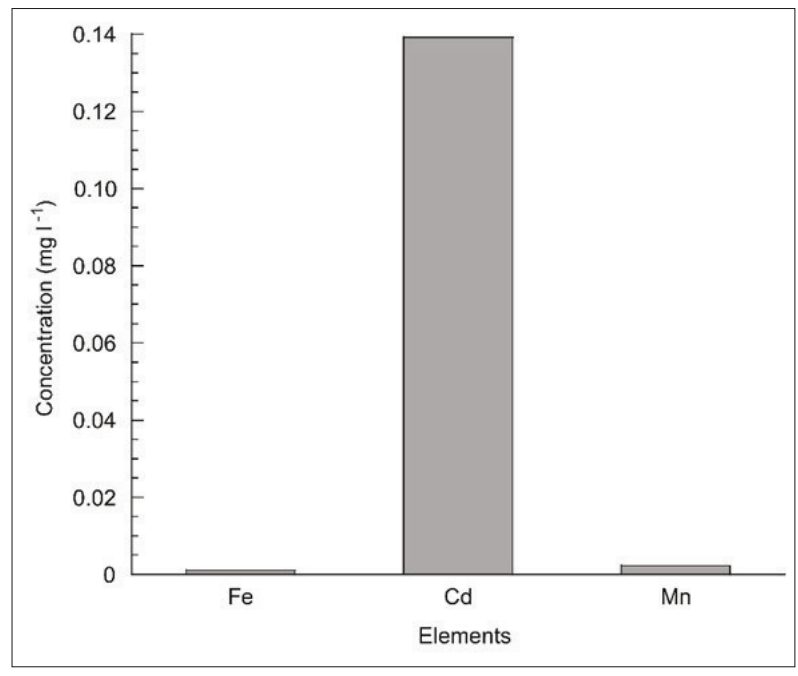

Figure 1: Concentration of $\mathrm{Fe}, \mathrm{Cd}$, and $\mathrm{Mn}$ ions present in water suspensions of powdered raw laterite

relatively high carbonate values for the raw laterite. In addition, raw laterite shows a higher abundance of $\mathrm{Cd}$ in filtrates relative to $\mathrm{Fe}$ and $\mathrm{Mn}$ (Figure 1). Consequently, $\mathrm{Cd}$ can be easily leached from laterite than $\mathrm{Fe}$ and $\mathrm{Mn}$ under normal soil $\mathrm{pH}$ conditions.

The geochemistry of laterites and lateritic soils significantly varies based on the location, climatic conditions, and depth. Layer thickness, geochemistry, and ore mineralogy of lateritic soils are determined by the degree of prolonged chemical weathering process. Laterites and their derivative soils contain $\mathrm{SiO}_{2}, \mathrm{Al}_{2} \mathrm{O}_{3}$, $\mathrm{Fe}_{2} \mathrm{O}_{3}$, and metals such as $\mathrm{K}, \mathrm{Mg}, \mathrm{Ca}, \mathrm{Ni}, \mathrm{Co}, \mathrm{Mn}, \mathrm{Cd}$, and Ti (Dissanayake, 1980; Gleeson et al., 2004; Fan \& Gerson, 2011; Nayanthika et al., 2018).

\section{Determination of optimum conditions for the leaching of $\mathrm{Fe}$ and $\mathrm{Mn}$ from laterite}

\section{Effective pH range}

Figure 2 shows variations in ion leaching capacities of selected elements with $\mathrm{pH}$. Accordingly, the Fe leaching concentration decreases suddenly with increasing $\mathrm{pH}$ values from 1 to 2 (Figure 2). Then, Fe leaching concentration slightly decreases with increasing $\mathrm{pH}$ from 1 to 5 . However, Fe concentrations are almost constant in $\mathrm{pH}$ values above 6 (Figure 2). Therefore, $\mathrm{pH}$ of 1 provides the highest leaching potential for $\mathrm{Fe}$ (17.69 ppm) with an enrichment factor of 17,690 compared to water solubility. 
Mn leaching efficiency also decreases gradually with increasing $\mathrm{pH}$ from 1 to 5 (Figure 2). Clear variations of $\mathrm{Mn}$ concentrations were not observed in $\mathrm{pH}$ values above 6 (Figure 2). Therefore, Mn can be leached under low $\mathrm{pH}$ conditions (Figure 2). However, Cd dissolution concentration gradually increases from $\mathrm{pH} 1$ to 10 (Figure 2 ). This suggests that $\mathrm{Cd}$ can be effectively leached under basic conditions, and the effective $\mathrm{pH}$ is $7(0.18 \mathrm{ppm}$ in Figure 2). Therefore, $\mathrm{Cd}$ does not leach well with $1 \mathrm{M}$ $\mathrm{HCl}$ at any $\mathrm{pH}$ value, though it leaches in water.

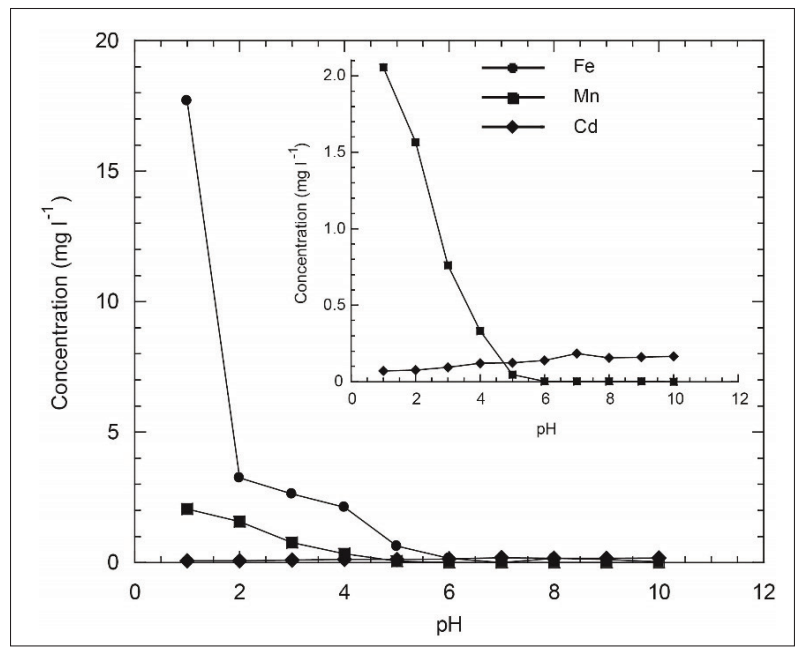

Figure 2: Variation of $\mathrm{Fe}, \mathrm{Mn}$, and $\mathrm{Cd}$ leaching concentrations with $\mathrm{pH}$

\section{Determination of optimum temperature}

Figure 3 shows variations of $\mathrm{Fe}$ and $\mathrm{Mn}$ ions leaching concentrations with temperature in $\mathrm{pH} 1$ solutions. $\mathrm{Fe}$ and $\mathrm{Mn}$ concentrations gradually increase with temperature (Figure 3). Therefore, temperature has a positive relationship with the leaching efficiency of $\mathrm{Fe}$ and $\mathrm{Mn}$ from laterite. The $\mathrm{Fe}$ leaching concentration at $40^{\circ} \mathrm{C}$ is $17.11 \mathrm{ppm}$ with an enrichment factor of 17,110 . However, Fe concentration increases up to $19.04 \mathrm{ppm}$ at $60{ }^{\circ} \mathrm{C}$ with an enrichment factor of 19,040 (Figure 3). Similarly, Mn leaching concentration slightly increases with temperature from $3.11 \mathrm{ppm}\left(40{ }^{\circ} \mathrm{C}\right.$; enrichment factor: 1,555$)$ to $3.18 \mathrm{ppm}\left(60{ }^{\circ} \mathrm{C}\right.$; enrichment factor: 1,590). According to Figure 3, the highest leaching capacity can be estimated at over $100{ }^{\circ} \mathrm{C}$. However, $\mathrm{HCl}$ evaporates at higher temperatures (Li et al., 2012).

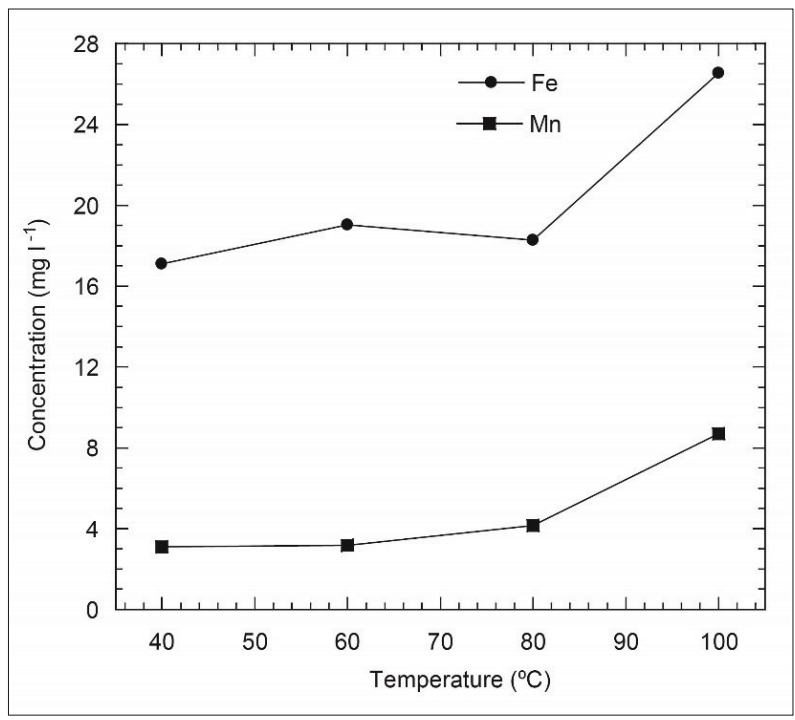

Figure 3: Variation of $\mathrm{Fe}$ and $\mathrm{Mn}$ leaching concentrations with temperature for $\mathrm{pH} 1$ solutions

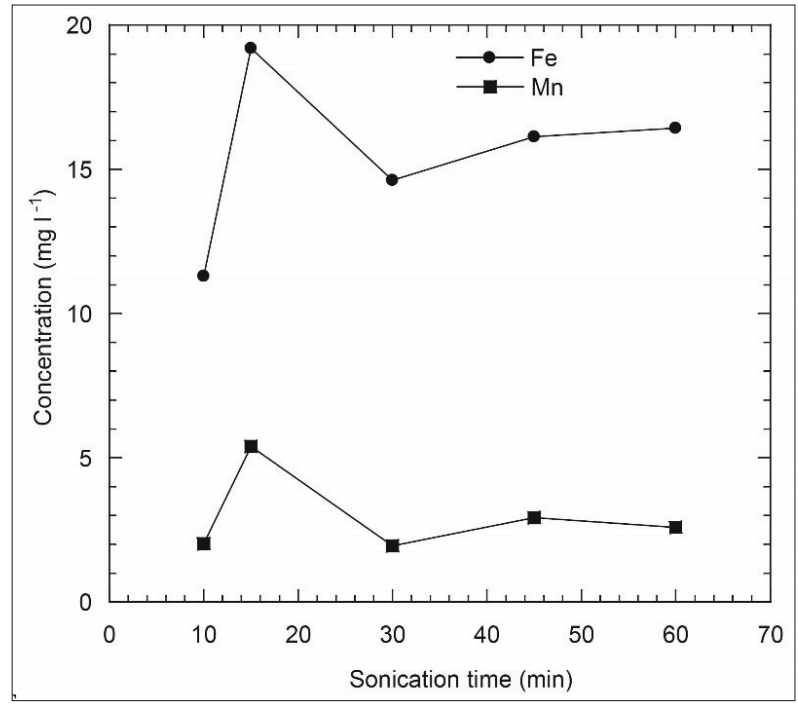

Figure 4: Variation of $\mathrm{Fe}$ and $\mathrm{Mn}$ leaching concentrations with sonication time for $\mathrm{pH} 1$ solutions

Moreover, heating adds additional operational costs. Therefore, industries prefer to maintain the temperature around $60{ }^{\circ} \mathrm{C}$ for leaching elements from raw materials (Patermarakis \& Paspaliaris, 1989).- 


\section{Determination of optimum sonication time}

Figure 4 shows variations of $\mathrm{Fe}$ and $\mathrm{Mn}$ ion leaching concentrations with sonication time in $\mathrm{pH} 1$ solutions. $\mathrm{Fe}$ and $\mathrm{Mn}$ ion leaching concentrations enhances with increasing sonication time from $10 \mathrm{~min}$ to $15 \mathrm{~min}$ (Figure 4). The highest Fe (19.19 ppm, enrichment factor: 19,190) and Mn (5.39 ppm; enrichment factor: 2,695) ions leaching concentrations can be observed in solutions sonicated for $15 \mathrm{~min}$. In contrast, the maximum leaching concentrations under the influence of temperature (Fe concentration $=26.56 \mathrm{ppm}$ and $\mathrm{Mn}$ concentration $=8.69$ ppm at $100{ }^{\circ} \mathrm{C}$ in Figure 4) are higher than the influence of sonication time (Fe concentration $=19.19 \mathrm{ppm}$ and $\mathrm{Mn}$ concentration $=5.39 \mathrm{ppm}$ ) at $15 \mathrm{~min}$ (Figure 4). However, sonication is preferred compared to heating in industrial applications (Kyllönen et al., 2004).

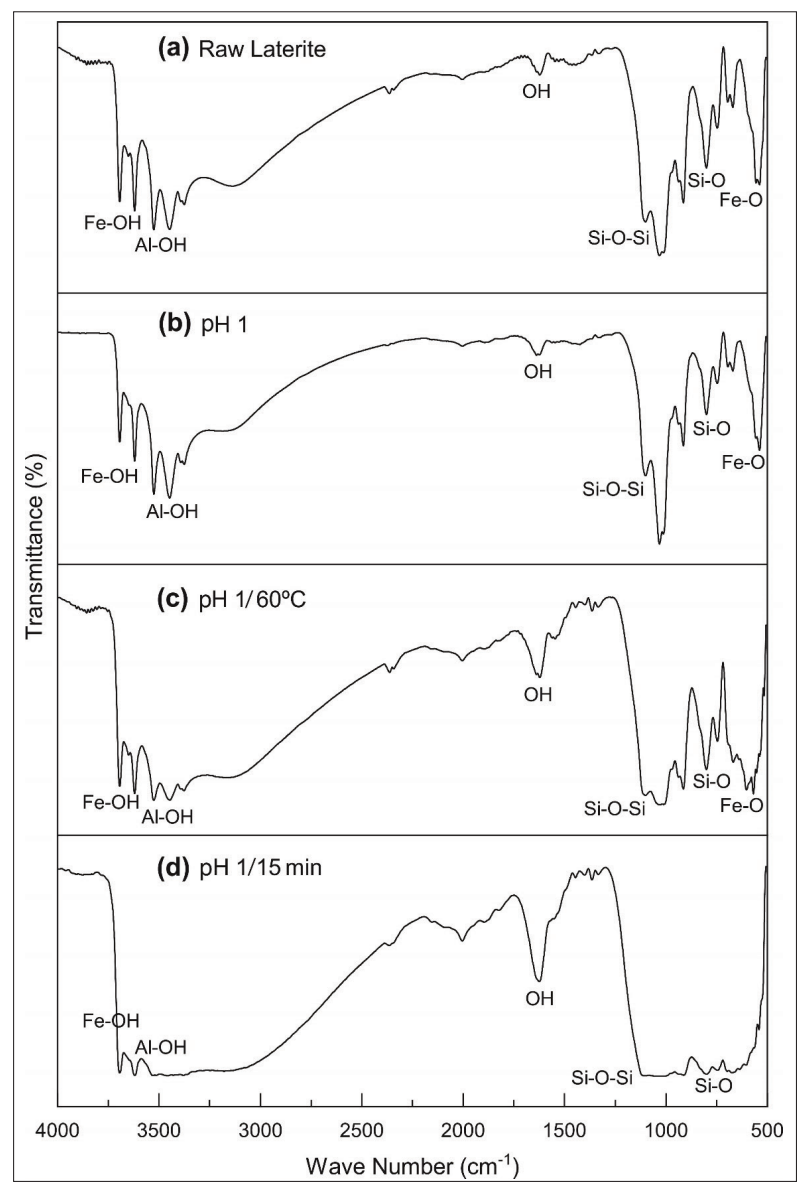

Figure 5: FTIR spectra of (a) untreated laterite sample, (b) acid leached ( $\mathrm{pH} 1$ solutions), (c) acid leached and heated $(\mathrm{pH}$ $\left.1 / 60^{\circ} \mathrm{C}\right)$, and $(\mathrm{d})$ acid leached and sonicated $(\mathrm{pH} 1 / 15$ min) samples.

\section{FTIR observations}

The untreated laterite sample shows IR transmittance peaks for $\mathrm{Fe}, \mathrm{Al}$, and silicon oxide/hydroxide bonds (Figure 5a). For example, IR transmittance within the range 3300-3700 $\mathrm{cm}^{-1}$ (Figure 5) indicates hydroxyl groups and inner hydroxyl groups of laterites (Nayanthika et al., 2018). Hydroxide groups of Fe, Al, and Si minerals are attributed to transmittance from $3370-3405 \mathrm{~cm}^{-1}$. The transmission band around $3500 \mathrm{~cm}^{-1}$ indicates $\mathrm{Al}-\mathrm{OH}$ stretching vibrations (Rathore et al., 2016). Furthermore, $914 \mathrm{~cm}^{-1}$ and $801 \mathrm{~cm}^{-1}$ peaks (Figure 5) indicate $\mathrm{Al}-\mathrm{OH}$ bending and $\mathrm{Fe}-\mathrm{OH}$ stretching vibrations, respectively (Mitra et al., 2016). In contrast, $1032 \mathrm{~cm}^{-1}$ peak suggests $\mathrm{Si}-\mathrm{O}-\mathrm{Si}$ stretching present in clay minerals (Rathore et al., 2016). FTIR transmittance bands at $672 \mathrm{~cm}^{-1}$ and $536 \mathrm{~cm}^{-1}$ (Figure 5) correspond to $\mathrm{Si}-\mathrm{O}$ bond in quartz and $\mathrm{Fe}-\mathrm{O}$ bond in hematite, respectively (Mitra et al., 2016; Rathore et al., 2016).

The peaks corresponding to iron oxides such as $\mathrm{Fe}-$ $\mathrm{OH}\left(801 \mathrm{~cm}^{-1}\right)$ and $\mathrm{Fe}-\mathrm{O}\left(536 \mathrm{~cm}^{-1}\right)$ are recorded in acid leached samples (pH 1 and $\mathrm{pH} 2$ solutions) (Figure 5b), and acid leached and heated $\left(\mathrm{pH} 1 / 60^{\circ} \mathrm{C}\right)$ samples (Figure $5 \mathrm{c})$. Therefore, it suggests that iron oxides remain in the precipitate after low $\mathrm{pH}$ acid leaching, and acid leaching at elevated temperatures (Figure 5b, c). Similarly, the peak corresponding to iron hydroxide $(\mathrm{Fe}-\mathrm{OH})$ can be observed in the acid leached and sonicated ( $\mathrm{pH}$ 1/15 min) sample (Figure 5d). However, the peak corresponding to $\mathrm{Fe}-\mathrm{O}$ bond in hematite has disappeared in the acid leached and sonicated ( $\mathrm{pH}$ 1/15 min) sample (Figure $5 \mathrm{~d})$. Therefore, the combination of acid leaching and sonication can be identified as the most effective method for Fe leaching from laterite samples.

\section{XRD observations}

Figure 6a shows that raw laterite indicates the presence of Fe-rich secondary minerals such as goethite substituted with $\mathrm{Al}\left(\left(\sim \mathrm{Fe}_{0.9} \mathrm{Al}_{0.1}\right) \mathrm{O}(\mathrm{OH})\right)$, hematite $\left(\mathrm{Fe}_{2} \mathrm{O}_{3}\right)$, and Alrich secondary minerals such as gibbsite $\left(\mathrm{Al}\left(\mathrm{OH}_{3}\right)\right)$. Kaolinite indicates the presence of clay minerals in laterite (Figure 6). Besides, goethite can occur in laterite as a weathering product of Fe-bearing minerals and as a direct precipitated agent from Fe-containing solutions (Mohapatra et al., 2008). Goethite is metastable under a wide range of environmental conditions and temperatures (Cornell et al., 1975) and has lower dissolution with $1 \mathrm{M} \mathrm{HCl}$ than hematite (Cornell \& Giovanoli, 1993). Consequently, the minor changes in peak positions and the increment of intensity in treated samples indicate that the Al-rich goethite in raw laterite has been converted to 
gibbsite after leaching, thus enhancing the Al content in the samples (Figure 6).

The occurrence of quartz peaks in raw laterite suggests the presence of silicate minerals as impurities (Figure 6). Quartz in laterite can be coated with Fe-oxides such as hematite. In addition, the reduction of the number of hematite peaks after treatment indicates that raw laterite has been successfully leached, liberating Fe ions into the solution (Figure 6). However, the remaining hematite peaks in the treated samples suggest the presence of small amount of $\mathrm{Fe}$ even after treatment. Thus, acid leached ( $\mathrm{pH} 1$ solutions), acid leached and heated $\left(\mathrm{pH} 1 / 60^{\circ} \mathrm{C}\right)$, and acid leached and sonicated ( $\mathrm{pH} \mathrm{1/15} \mathrm{min}$ ) samples recorded more gibbsite peaks suggesting successful Al enhancement (Figure 6b, c, d).

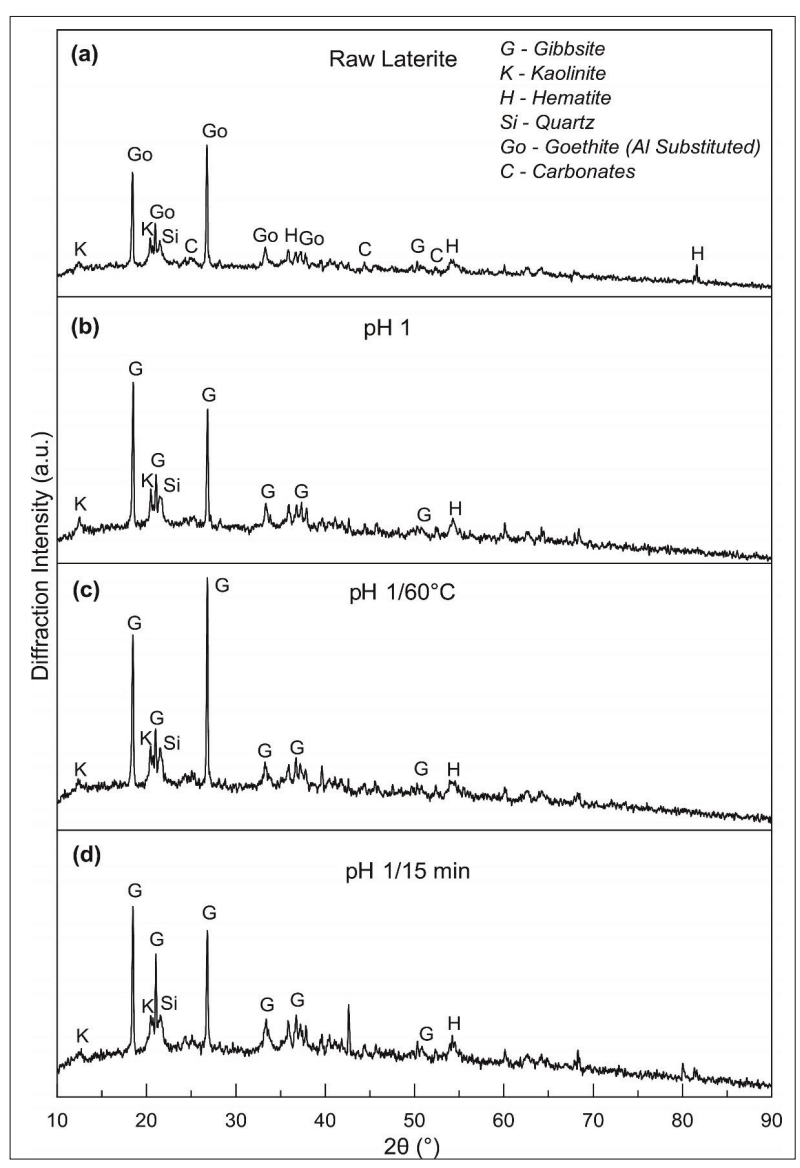

Figure 6: XRD spectra of (a) raw laterite, (b) acid leached ( $\mathrm{pH} 1$ solution), (c) acid leached and heated $\left(\mathrm{pH} 1 / 60^{\circ} \mathrm{C}\right)$, and (d) acid leached and sonicated ( $\mathrm{pH} 1 / 15 \mathrm{~min}$ ) samples

\section{CONCLUSIONS}

XRD results show goethite and hematite as main Ferich secondary minerals in Sri Lankan raw laterite. The $\mathrm{Fe}$ and $\mathrm{Mn}$ leaching efficiencies decrease with increase in $\mathrm{pH}$ from 1 to 5 . The $\mathrm{Cd}$ leaching efficiency increase with $\mathrm{pH}$ from 1 to 10 . Therefore, the Fe and Mn leaching efficiencies are controlled by hydrogen ion concentration. In contrast, $\mathrm{Cd}$ leaching was controlled by hydroxyl ion concentration. The $\mathrm{Fe}$ in the leachate obtained after treating at $\mathrm{pH} 1$ showed a Fe enrichment factor of 17,690. Fe and $\mathrm{Mn}$ leaching efficiencies increased with temperature from $40{ }^{\circ} \mathrm{C}$ to $100{ }^{\circ} \mathrm{C}$. However, $\mathrm{pH}$ 1 , temperature $60{ }^{\circ} \mathrm{C}$, and $15 \mathrm{~min}$ sonication time were determined as optimum industrial applicable conditions for Fe leaching from Sri Lankan laterite. Sonication for $15 \mathrm{~min}$ at $60{ }^{\circ} \mathrm{C}$ in $\mathrm{pH}$ of 1 was determined as the optimum condition for Mn leaching from Sri Lankan laterite, with an enrichment ratio of 2,695 in the leachate. The goethite found in laterite used in this study is $\left(\sim \mathrm{Fe}_{0.9} \mathrm{Al}_{0.1}\right) \mathrm{O}(\mathrm{OH})$ ) according to $\mathrm{XRD}$ analysis and this goethite would react with concentrated acid to form gibbsite and $\mathrm{FeCl}_{3}$. Leaching $\mathrm{Fe}$ and $\mathrm{Mn}$ enhance the $\mathrm{Al}$ content present in laterite. Consequently, the upgraded laterite could be used in applications, such as an additive to adjust $\mathrm{Al}$ content in clinker during cement production. The leachate could be a potential source of Mn and Fe.

\section{Acknowledgement}

This research was supported by the Accelerating Higher Education Expansion and Development (AHEAD) Operation of the Ministry of Higher Education funded by the World Bank. The authors thank M.D. Nilantha, Sandun Wijerama, and Pradeep Ranathunga for assistance in laboratory work.

\section{REFERENCES}

Ayanda O.S., Adekola F.A., Baba A.A., Fatoki O.S. \& Ximba B.J. (2011). Comparative study of the kinetics of dissolution of laterite in some acidic media. Journal of Minerals and Materials Characterization and Engineering 10(15): 1457-1472.

DOI: https://doi.org/10.4236/jmmce.2011.1015113

Çetintaş S. \& Bingöl D. (2020). Performance evaluation of leaching processes with and without ultrasound effect combined with reagent-assisted mechanochemical process for nickel recovery from laterite: Process optimisation and kinetic evaluation. Minerals Engineering 157(01): 106562. 
DOI: https://doi.org/10.1016/j.mineng.2020.106562

Cornell R.M. \& Giovanoli R. (1993). Acid dissolution of hematites of different morphologies. Clay Minerals 28(02): 223-232.

DOI: https://doi.org/10.1180/claymin.1993.028.2.04

Cornell R.M., Posner A.N.M. \& Quirk J.P. (1975). The complete dissolution of goethite. Journal of Applied Chemistry and Biotechnology 25(09): 701-706

DOI: https://doi.org/10.1002/jctb.5020250909

Dahanayake K. (1982). Laterites of Sri Lanka - a reconnaissance study. Mineralium Deposita 17(02): 245-256.

DOI: https://doi.org/10.1007/BF00206474

Dissanayake C.B. (1980). Mineralogy and chemical composition of some laterites of Sri Lanka. Geoderma 23(02): 147-155.

DOI: https://doi.org/10.1016/0016-7061(80)90016-6

Dissanayake D.M.S.N., Mantilaka M.M.M.G.P.G., Palihawadana T.C., Chandrakumara G.T.D., De Silva R.T., Pitawala H.M.T.G.A., Nalin de Silva K.M. \& Amaratunga G.A.J. (2019). Facile and low-cost synthesis of pure hematite $\left(\alpha-\mathrm{Fe}_{2} \mathrm{O}_{3}\right)$ nanoparticles from naturally occurring laterites and their superior adsorption capability towards acid-dyes. RSC Advances 9(37): 21249-21257. DOI: https://doi.org/10.1039/C9RA03756J

Fan R. \& Gerson A.R. (2011). Nickel geochemistry of a Philippine laterite examined by bulk and microprobe synchrotron analyses. Geochimica et Cosmochimica Acta 75(21): 6400-6415.

DOI: https://doi.org/10.1016/j.gca.2011.08.003

Gleeson S.A., Herrington R.J., Durango J., Velásquez C.A. \& Koll G. (2004). The mineralogy and geochemistry of the Cerro Matoso SA Ni laterite deposit, Montelíbano, Colombia. Economic Geology 99(06): 1197-1213.

DOI: https://doi.org/10.2113/gsecongeo.99.6.1197

Goswami R.K. \& Mahanta C. (2007). Leaching characteristics of residual lateritic soils stabilised with fly ash and lime for geotechnical applications. Waste Management 27(04): 466-481.

DOI: https://doi.org/10.1016/j.wasman.2006.07.006

Heiri O., Lotter A.F. \& Lemcke G. (2001). Loss on ignition as a method for estimating organic and carbonate content in sediments: reproducibility and comparability of results. Journal of Paleolimnology 25(01): 101-110. DOI: https://doi.org/10.1023/A:1008119611481

Herath J.W. \& Pathirana H.C.N.C. (1983). Genesis and constitution of Sri Lanka laterites. Journal of the National Science Council of Sri Lanka 11(02): 277-292.

DOI: http://doi.org/10.4038/jnsfsr.v11i2.8390

Ilyas S., Srivastava R.R., Kim H., Ilyas N. \& Sattar R. (2020). Extraction of nickel and cobalt from a laterite ore using the carbothermic reduction roasting-ammoniacal leaching process. Separation and Purification Technology 232: 115971.

DOI: https://doi.org/10.1016/j.seppur.2019.115971

Kyllönen H., Pirkonen P., Hintikka V., Parvinen P., Grönroos A. \& Sekki H. (2004). Ultrasonically aided mineral processing technique for remediation of soil contaminated by heavy metals. Ultrasonics Sonochemistry 11(03-04): 211-216.
DOI: https://doi.org/10.1016/j.ultsonch.2004.01.024

Li J., Xiong D., Chen H., Wang R. \& Liang Y. (2012). Physicochemical factors affecting leaching of laterite ore in hydrochloric acid. Hydrometallurgy 129-130(01): 14-18. DOI: https://doi.org/10.1016/j.hydromet.2012.08.001

Liu K., Chen Q., Hu H. \& Yin Z. (2010). Characterisation and leaching behavior of lizardite in Yuanjiang laterite ore. Applied Clay Science 47(03-04): 311-316. DOI: https://doi.org/10.1016/j.clay.2009.11.034

Maiti A., Basu J.K. \& De S. (2012). Experimental and kinetic modeling of $\mathrm{As}(\mathrm{V})$ and $\mathrm{As}(\mathrm{III})$ adsorption on treated laterite using synthetic and contaminated groundwater: Effects of phosphate, silicate and carbonate ions. Chemical Engineering Journal 191(01): 1-12.

DOI: https://doi.org/10.1016/j.cej.2010.01.031

Mitra S., Thakur L.S., Rathore V.K. \& Mondal P. (2016). Removal of $\mathrm{Pb}(\mathrm{II})$ and $\mathrm{Cr}(\mathrm{VI})$ by laterite soil from synthetic waste water: single and bi-component adsorption approach. Desalination and Water Treatment 57(39): 18406-18416. DOI: https://doi.org/10.1080/19443994.2015.1088806

Mohapatra B.K., Jena S., Mahanta K. \& Mishra P. (2008). Goethite morphology and composition in banded iron formation, Orissa, India. Resource Geology 58(03): 325332.

DOI: https://doi.org/10.1111/j.1751-3928.2008.00065.x

Moutei L., Benbrahim Y., Bouih A., Labied S., Guedira T. \& Benali O. (2018). The effect of the addition of alumina powder on the confinement properties of a cement mortar. In MATEC Web of Conferences 149: 01055.

DOI: https://doi.org/10.1051/matecconf/201814901055

Nasab M.H., Noaparast M., Abdollahi H. \& Amoozegar M.A. (2020). Indirect bioleaching of $\mathrm{Co}$ and $\mathrm{Ni}$ from iron rich laterite ore, using metabolic carboxylic acids generated by $P$. putida, P. koreensis, P. bilaji and A. niger. Hydrometallurgy 193(01): 105309.

DOI: https://doi.org/10.1016/j.hydromet.2020.105309

Nayanthika I.V.K., Jayawardana D.T., Bandara N.J.G.J., Manage P.M. \& Madushanka R.M.T.D. (2018). Effective use of iron-aluminum rich laterite based soil mixture for treatment of landfill leachate. Waste Management 74(01): 347-361.

DOI: https://doi.org/10.1016/j.wasman.2018.01.013

Patermarakis G. \& Paspaliaris Y. (1989). The leaching of iron oxides in boehmitic bauxite by hydrochloric acid. Hydrometallurgy 23(01): 77-90.

DOI: https://doi.org/10.1016/0304-386X(89)90019-4

Perks C. \& Mudd G. (2019). Titanium, zirconium resources and production: a state of the art literature review. Ore Geology Reviews 107(01): 629-646.

DOI: https://doi.org/10.1016/j.oregeorev.2019.02.025

Persons B.S. (2012). Laterite: Genesis, Location, Use. Springer Science \& Business Media, Germany.

Pham T.D., Pham T.T., Phan M.N., Ngo T.M.V. \& Vu C.M. (2020). Adsorption characteristics of anionic surfactant onto laterite soil with differently charged surfaces and application for cationic dye removal. Journal of Molecular Liquids 301(01): 112456.

DOI: https://doi.org/10.1016/j.molliq.2020.112456 
Rathore V.K., Dohare D.K. \& Mondal P. (2016). Competitive adsorption between arsenic and fluoride from binary mixture on chemically treated laterite. Journal of Environmental Chemical Engineering 4(02): 2417-2430.
DOI: https://doi.org/10.1016/j.jece.2016.04.017

The Aluminium Association (2020). Available at https://www. aluminum.org/industries/production/alumina-refining, Accessed August 2020. 